\author{
Professor Marta-Christina SUCIU, PhD \\ Faculty of Theoretical and Applied Economics \\ The Bucharest University of Economic Studies \\ E-mail: Christina.suciu@economie.ase.ro \\ Professor Mirela CRISTEA, PhD* (Corresponding author) \\ University of Craiova, Faculty of Economics and Business \\ Administration, Department of Finance, Banking and \\ Economic Analysis \\ Center for Banking and Financial Research \\ E-mail: mirelas.cristea@gmail.com \\ Associate Professor Graţiela Georgiana NOJA, PhD \\ West University of Timişoara, Faculty of Economics and \\ Business Administration, Department of Marketing and \\ International Economic Relations, East European Center for \\ Research in Economics and Business \\ E-mail: gratiela.noja@e-uvt.ro
}

\title{
IMMIGRATION EFFECTS WITHIN THE EU-BREXIT FRAMEWORK: AN EMPIRICAL ANALYSIS
}

\begin{abstract}
This research aims to assess the Brexit spillovers upon ten EU economies (EU-10), through labour mobility, as a core pillar of regional integration. In this regard, we have developed two scenarios on the outputs obtained by EU-10related to GDP growth and labour market main results both for natives and the foreign population under the effects of labour and humanitarian immigration flows framed within the Brexit context (2000-2019). We have built up a panel consisting of representative indicators that have been standardised in order to ensure accurate results for the specific macro-econometric and structural equations models(SEM) applied. The results highlight that the EU-10 will be positively influenced by immigration considering the labour market outcomes, as revealed by important employment levels increases, even though the impact largely differs across countries, under a compelling spatial presence.
\end{abstract}

Keywords: immigration flows, Brexit, European integration, economic growth, labour market, econometric modelling.

JEL Classification: F15, F22, F63.

\section{INTRODUCTION}

European economic integration resides on granting the four basic freedoms of movement, with labour mobility as one of the most controversial pillar that weighted heavily also in the Brexit decision.

\footnotetext{
DOI: $10.24818 / 18423264 / 52.4 .18 .08$
} 


\section{Marta-Christina Suciu, Mirela Cristea, Graţiela Georgiana Noja}

The Brexit vote in 2016 was influenced in a great manner by natives' reluctance towards migrants that has increased during the latest years, especially in the background of the refugee crisis in Europe (Clarke and Whittaker, 2016; Parker, 2017), and highlights the risk of hardening barriers for labour movement within the EU. This situation regards mostly the low-skilled workers that might also bring an unfavourable spillover impact on the high-skilled workforce mobility and correspondingly on the potential impact for long-run economic development in migrants' countries (both for the sending and hosting states).

Within the Brexit framework, several studies had highlighted the potential impact upon European economies through multiple channels, like foreign direct investment (FDI), trade, financial services, industrial policies, settlements, fiscal involvement, living standard (expressed mostly in terms of income), while migration has been often comprised as a fundamental influential factor (e.g. Booth et al., 2015; Beggand Mushövel, 2016;Portes, 2016; Jafari and Britz, 2017; Simionescu et al., 2017).

Although there are several studies considering migration implications after Brexit, these have mostly investigated the impact for the UK economy(e.g. Kierzenkowski et al., 2016; Jafari and Britz, 2017; Parker, 2017; Portesand Forte, 2017), and fewer for the otherEU-27 Member States (MS)and the UK (Irwin, 2015; Beggand Mushövel, 2016;Simionescu et al., 2017).

Based on various implications of migration within the Brexit outlook and few researches which analysed these credentials for all or correspondingly for a group of EU MS, the main objective of our paper is to examine the Brexit spillovers upon ten EU MS (EU-10) most targeted by migrants (including the UK) through the free movement of persons (labour mobility), as a core pillar of regional integration. Different from other similar researches, we have built up a complex panel of EU10 MS, considered for the 2000-2019 time span(2019 representing the time limit for Brexit negotiations, which have started in 2017). Furthermore, we have analysed based on Stata program a complex set of indicators (200 observations per each) that have been next extrapolated and standardised in order to obtain accurate results from the appropriate macro-econometric models and structural equations modelling (SEM).

The paper is structured on three main parts: after a brief introduction on the research topic's importance, the first part presents a brief review of the specialised literature; in the second part we have detailed the data used for the empirical analysis and the methodological endeavour, while the last part comprises the main research results, discussions and final remarks.

\section{BRIEF LITERATURE REVIEW}

Numerous scenarios regarding the implications of the UK's decision to leave the UE were investigated by researchers, both forwards, and after the Brexit decision vote (June 2016).

The effects of migration after Brexit would highly depend on the new partnerships stated and conditions negotiated by the UK. 
Immigration Effects within the EU-Brexit Framework: An Empirical Analysis

In this regard, Booth et al. (2015) investigated the implications of regulation, trade and labour migration for the UK's economy.

They took into account four potential alternatives of what kind of partnerships UK might select after Brexit, as follows: (1) there is no new partnership with the remaining EU MS; (2) a Free Trade Agreement (FTA)negotiated with the EU-27; (3) a combination of the FTA stated with the EU, and another one with the rest of the world; (4) it drops out any participation to the EU budget. For the first two scenarios, all the variables investigated would generate a loss for the UK's GDP (estimated to be greater for the first scenario), while for the last two scenarios we might anticipate these would result in a gain of GDP (predicted to be higher for the $4^{\text {th }}$ scenario).

The research performed by Irwin (2015) represents one of the most extensive studies dedicated to this particular topic, focusing on the Brexit implications upon the UK and the other EU-27. Irwin measured the impact intensity (impact scale) of 10 variables (channels) by applying the multiple metrics score. The variables considered were: immigration, FDI, regulation, industrial policies, budget, financial services, trade, international influence, uncertainty. The results obtained revealed high and unfavourable effects for the UK's economy. The impact intensity of Brexit upon the remaining EU-27 countries was grouped into four categories, corresponding to a very high, high, medium and low impact. As regards migration, the expected effects are on a medium scale (on the niche), especially for Poland.

Begg and Mushövel (2016) analysed the GDP effects of migration, employment opportunities, and public finances, also for the EU-27 and the UK. They focus their debate on the main scenarios (short and long-term) accounted by a group of economists. Their results revealed that, there might be expected negative implications both for the UK, and for the EU-27, concerning mostly the short-term; it is anticipated a GDP variation ranging between a $10 \%$ loss to a $4 \%$ growth, according to different economists, for the long run. As regards migration, positive effects might happen, since EU migrants "are significantly more likely to be in employment than their indigenous counterparts and make a positive contribution to the UK's public finances" (Begg and Mushövel, 2016: 4).

The effects for the UK's economy determined by immigration, alongside with trade, skills, confidence, FDI and deregulation were studied by Kierzenkowski et al. (2016). These authors consider that GDP would be over 3\% lower by 2020 (near term), and over 5\% until 2030 (longer term), since “... structural impacts would take hold through the channels of capital, immigration and lower technical progress" (Kierzenkowski et al. 2016: 5).

The combined implications of trade, reduced EU labour immigration, and FDI might generate a total GDP decrease of over $3 \%$ for the UK, as outlined by Jafari and Britz (2017). Parker (2017) examined the political implications for migrants after Brexit. The author started from the presumption of an "obviously impact adversely on national labour markets" of migration (Parker, 2017: 11). 


\section{Marta-Christina Suciu, Mirela Cristea, Graţiela Georgiana Noja}

Parker revealed that it is expected to register "a net economic positive impact" of migration from EU MS in the case of the UK, according to "a progressive politics". Implication of flows and migration policies upon the UK would determine the raising in regulatory burdens with anticipated effects on decreasing the output of unskilled and skilled labour "... and an increase in illegal working" (Portes, 2016: 20).

Portes and Forte (2017) have studied the effects for the UK's economy of migration, employment, salaries, and development. They highlighted that the decreases in migration "are likely to have a significant negative impact on the UK $G D P$ per capita (and GDP), with marginal positive impacts on wages in the lowskill service sector" (Portes and Forte, 2017: S31). Sampson (2017), attempting to explain better the main findings of Portes and Forte (2017), supposed these impacts would be significant, "particularly for sectors such as finance that rely on access to highly skilled workers from across the EU" (Sampson, 2017: 173).

Various researches (Boubtaneet al., 2015; Comes et al., 2018) proved that migration leads to significant higher economic impacts than FDI or trade, expressed especially in terms of productivity and real GDP growth. These results are justified, on one hand, by pointing out the relevance of intellectual capital and high-skilled migrants (skill composition of migration), also highlighted by Roman and Popescu (2015), and Boboc et al. (2015). On the other hand, Parker (2017) outlined, in the Brexit context, that "even in the UK case where the issue has been most controversial and politicised, the evidence suggests a net economic positive impact of EU migration" (Parker, 2017: 23). Boswell (2016) and Booth et al. (2015) underlined the necessity for better training and education policies (ALMPs) for natives (e.g. British labour force) since a significant reduction of labour might generate damaging effects. Marcu and Dobrotă (2017), as well as Netoiu et al. (2014), underlined the need for innovation, encouraging investments in lifelong learning \&education, flexible and adaptable labour market policies, in order to reduce the poverty rate, to support economic and social developments and to decrease the inequalities among MS.

Based on the literature review, we can conclude that there are many studies that investigated the Brexit impacts through migration, both on the UK (as a focus point for most of the researches) and on the EU MS (fewer studies), but, as far as we know, none of these applies an extensive methodology and various models to ensure proper results and interpretations. Nevertheless, in addition to being designed as a comprehensive study focusing on the immigration effects in EU-10 countries most targeted by migrants under the Brexit perspective, this research broadens the foresight of performances achieved by these countries expressed in terms of GDP growth and labour market outcomes, revealed both in the case of own and outside population. 
Immigration Effects within the EU-Brexit Framework: An Empirical Analysis

\section{DATA AND METHODOLOGY}

By investigating the main findings of the literature, lined up to our general main research objective, we have designed our analysis such as to include in the panel the following data (variables):

i) international migration variables: immigrants'flows (IMIG); asylum seekers inflows (number of applications) (ASYL);

ii) economic development, labour market and related representative variables: GDP growth rate (GDP_growth) (\%); employment rate (ER, ER_F) and unemployment rate (UR, UR_F) (\%) of total and foreign population (F); at-risk-ofpoverty rate (POV_R); annual net earnings of a two-earner married couple with two children (EARN) (euro); educational level reflected through the educational attainment for tertiary education (EDU_tert), and the participation rate in education and training (EDU_part); the active labour market policies (ALMPs), and the passive labour market policies (PLMPs); life expectancy at birth (LE); business enterprise $R \& D$ expenditures for the business enterprise sector as a percentage of the GDP (BERD); Gini coefficients (index) (GINI);

iii) globalization variables: KOF Index of Globalization - overall (total) and economic dimensions (KOF_T, KOF_E).

The general panel covers the EU-10MS most targeted by migrants for 20002019time period, based on the statistical data for 2000-2015. We have proceeded to use extrapolation as a mathematical method, for the 2016-2019 series, to forecast a sample of the statistical data expected evolution.The databases used for collecting our variables(200 observations per each group of variables) are: ETH Zurich, Eurostat (European Commission);Organisation for Economic Co-operation and Development (OECD); Un Refugee Agency (UNHCR);World Development Indicators (World Bank).

Regarding the international migration situation, in 2015, the total number of migrants in Europe (over 76 million people) has increased with almost 4 million people compared to 2014, representing $31.25 \%$ from the total stock of migrants at the worldwide level (over 243 million persons) (UN DESA, 2015). In 2015, the most targeted EU-10 MS by migrants were: "Germany (12 million migrants stock), the United Kingdom (8.5 million), France (7.8 million), Spain (5.9 million), Italy (5.8 million), Sweden (1.6 million), Austria (1.5 million), Belgium (1.4 million), Denmark (572 thousands), Finland (315 thousands)"(Noja et al., 2018: 6). Bilaterally, the main migrant sending economies are in fact developing countries, looking for cross-border jobs (e.g. Poland, with 3.6 million of migrants, Romania, almost 3 million). As a result of the Brexit vote, the flow of immigrants in the UK declined slightly in 2016 compared with the previous year, while emigration rose due to the insecurities brought by the Brexit vote (Eurostat, 2017).

The refugees' statistics, at the level of 2016 year, counted 22.5 million moved away people, being considered "the highest on record, although the annual rate of growth has slowed since 2012" (OECD, 2017). 


\section{Marta-Christina Suciu, Mirela Cristea, Graţiela Georgiana Noja}

Large shares of asylum seekers in Europe were registered by Germany and Italy, "Germany remained the top recipient, with over 720,000 applications, followed by the United States (262,000) and Italy (123,000)" (OECD, 2017: 32).

Hence, Europe is confronting nowadays with double flows of international migration: (1) the labour migration flows, especially coming from European emergent developing countries(labour or economic migration); (2) growing flows of refugees and asylum seekers, forced by political incertitude or poverty to leave their countries and to look for international security (humanitarian migration). These two types of specific migration flows induce direct or indirect connections to the expected outcomes in different economic fields, mainly on the labour market. All of these flows bring major economic transformation and are therefore considered to be very significant and relevant for our analyse from an empirical point of view.

In the methodological endeavour, we have firstly applied the standardisation procedure for the indicators used in the empirical analysis and we have suggested the use of a composite indicator determined according to the equation (1) (OECD, 2005):

$$
y_{i}=\frac{x_{i}-\text { mean }}{s d},
$$

where: $x_{i}$ represents the crude value of the indicator; and $s d$ is the standard deviation. Thus, the standardisation method allowed us to convert all indicators to a common scale (standard deviation of the indicator across countries is the scaling factor) to provide a suitable comparability and statistical representativeness of data among countries in order to avoid aggregation distortions.

Furthermore, the impact of economic(labour) immigration upon labour market outcomes and economic growth of the receiving economies under the implications of Brexit spillovers was investigated based on distinctive macro-econometric models and associated next methods specific to Stata program. Thus, we have configured and processed a general model through random and fixed effects (FE or RE - model 1, with results reported according to the Hausman test), spatial analysis (spatial lag - model 2, and lag bootstrap - model 3, respectively spatial error model 4, and error bootstrap - model 5), robust regression (REG, general-model 6, and bootstrap - model 7), and panel corrected standard errors (PCSE - model 8).

The macro-econometric model for the migration-GDP_growth impact is designed as a baseline panel regression model (2a), but reshaped through the spatial procedures (lag, $2 \mathrm{~b}$, and error, $2 \mathrm{c}$ ), according to equations (2a), (2b) and (2c).

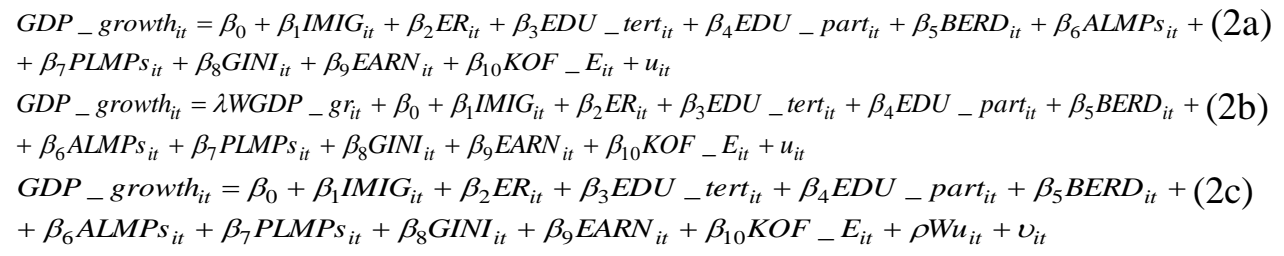


Immigration Effects within the EU-Brexit Framework: An Empirical Analysis

The general model developed for assessing the impacts of immigration (labour) upon the employment rate (as the main labour market indicator), both for own and the outside (foreign) population, has the following configuration (equation $2 \mathrm{~d}$ ):

$E R_{i t}=\beta_{0}+\beta_{1} I M I G_{i t}+\beta_{2} E D U_{-}$tert $_{i t}+\beta_{3} E D U_{-}$part $_{i t}+\beta_{4} B E R D_{i t}+\beta_{5} A L M P s_{i t}+\beta_{6} P L M P s_{i t}+(2 \mathrm{~d})$ $+\beta_{7} \operatorname{GINI}_{i t}+\beta_{8} E{ }^{2} N_{i t}+\beta_{9}$ KOF $-E_{i t}+u_{i t}$

The spatial autocorrelation presence (or absence) is validated through Patrick Moran (Moran's I) test by equation (3) (Viton, 2010).

$$
I=\frac{R}{\sum_{i} \sum_{j} \omega_{i j}} \frac{\sum_{i} \sum_{j} \omega_{i j}\left(x_{i}-\bar{x}\right)\left(x_{j}-\bar{x}\right)}{\sum_{i}\left(x_{i}-\bar{x}\right)^{2}}
$$

In order to provide substantial estimates of our analysis, we have also determined bootstrap sampling, estimation on spatial models and robust regression. These methods ,allow assigning measures of accuracy (defined in terms of bias, variance, confidence intervals, prediction error or some other such measure) to sample estimates" (Efron and Tibshirani, 1993: 10).

Moreover, in order to enclose and highlight the connections (direct, indirect and total) among immigration, the labour market results and GDP growth we have applied structural equations modelling (SEM). SEM is a multivariate data analysis, which tests and forecasts causal links among selected variables, being an inclusive and high modelling technique. SEM is configured through the following system of equations: (4).

$$
\left\{\begin{array}{l}
b_{11} y_{2 t}+\ldots .+b_{1 m} y_{m t}+c_{1 I} x_{1 t}+\ldots+c_{1 n} x_{n t}=\varepsilon_{1 t} \\
b_{21} y_{2 t}+\ldots .+b_{2 m} y_{m t}+c_{21} x_{1 t}+\ldots+c_{2 n} x_{n t}=\varepsilon_{2 t} \\
\ldots \ldots \ldots . . \\
b_{m I} y_{1 t}+\ldots .+b_{m m} y_{m t}+c_{m I} x_{n t}+\ldots+c_{m n} x_{n t}=\varepsilon_{m t}
\end{array},\right.
$$

where: $t$ is the observed time periods (number); $b_{i j}$ represents the parameters of $\mathrm{y}_{\mathrm{ij}}$ endogenous variables; $c_{i j}$ are the parameters, $\mathrm{i}=1, \ldots, \mathrm{m}$, of the $\mathrm{x}_{\mathrm{ij}}$ exogenous variable; $j=1, \ldots, n$.

\section{MAIN RESULTS AND DISCUSSIONS}

\subsection{Macro-econometric modelling: migration impact models}

In line with our main research objective and following the methodological endeavour, we have designed the macro-econometric models such as to estimate the labour immigration effects on host countries' economic growth and correspondingly the employment performances of natives and foreign population according to the Brexit framework. We applied eight procedures, namely:fixed effects (model 1 - the FE were stored after running also the random effects and performed the Hausman test which was in favour of the FE models: chi2 $(10)=73.90 ; \mathrm{p}=0.000$ ); spatial analysis (spatial lag - model 2 and lag bootstrap - model 3; spatial error - model 4 and error bootstrap - model 5);robust regression (general-model 6and robust bootstrap-model 7; robust regression was performed even to discard variations among host countries since the panel could be 


\section{Marta-Christina Suciu, Mirela Cristea, Graţiela Georgiana Noja}

entirely driven by larger economies, such as, for example, Germany, France);and panel corrected standard errors (PCSE - model 8).

A description of the statistics variables considered for the analysis is presented in Appendix, Table A1. Panel unit-root tests applied (Levin-Lin-Chu, Im-PesaranShin, Harris Tzavalis and Fisher-type based on Augmented Dickey-Fuller presented in the Appendix, Table A2) reveal that this problem is discarded in favour of stationarity. Although the estimated coefficients are slightly different in size, they are consequent in sign throughout all the applied econometric procedures, the results being robust and thus properly interpreted.

In the case of spatial analysis, both spatial lag and spatial error models have been applied, taking into account the fact that by ignoring a spatial lag leads to biased and inconsistent estimation of the parameters, while ignoring a spatial error leads to inefficient estimation of the parameters and to a biased residual variance. Therefore, the spatial lag model is built up such as to contain the spatial lag of the dependent variable in enclosed locations used as an extra explanatory variable.

The Moran's I tests reveal a positive global spatial autocorrelation ( $\mathrm{I}_{\mathrm{GDP} \_ \text {growth }}=0.198, \mathrm{p}=0.000 ; \mathrm{I}_{\mathrm{ER}}=0.084, \mathrm{p}=0.000 ; \mathrm{I}_{\mathrm{ER} \_\mathrm{F}}=0.060, \mathrm{p}=0.000$ ). Therefore, the results obtained by the neighbouring locations are also conclusive for assessing the impact upon economic growth and labour market outcomes of considered host economies under the compelling effects of immigration.

If we consider the immigration impact upon GDP growth rates (Table 1), the results reveal that in the Brexit framework this is expected to have a negative effect since the estimated coefficients associated with IMIG variable are negative, but with a small degree of statistical significance (below the $10 \%$ level). On the other hand, when we have accounted for the immigration impact on labour market outcomes for natives and for the foreign population residing in the EU-10 migrant receiving economies considered, the results are positive and extremely significant (at $0.1 \%$ level)(Table 2), thus highlighting a major contribution of economic migrants to the overall employment performances of host countries.

Thus, the results further reveal a strong positive impact induced by additional immigration inflows upon the labour market outcomes of EU-10. This is reflected by a significant increase in employment levels, both total, on the aggregate level, but especially for the foreign people (positive coefficients associated with the IMIG variable as shown in Table 2 and Table A3 in the Appendix).

In this regard, another positive credential is represented by the educational background, highly skilled tertiary educated labour (EDU_tert) having a major contribution both for economic growth (GDP_growth) and for the employment outcomes, under the compelling effects of spatial spillovers. Moreover, an additional effort made to support research and development (revealed by the upward of BERD) positively reflects on labour market results expressed by an increase in total employment rate. 
Immigration Effects within the EU-Brexit Framework: An Empirical Analysis

Table 1. Results of GDP_growth-migration macro-econometric impact models

\begin{tabular}{|c|c|c|c|c|c|c|c|c|}
\hline \multicolumn{9}{|c|}{ Dependent Variable : GDP_growth_st } \\
\hline \multirow[b]{2}{*}{ Variables } & (1) & (2) & (3) & (4) & (5) & (6) & (7) & (8) \\
\hline & $F E$ & Spatial lag & $\begin{array}{c}\text { Spatial lag } \\
\text { bootstrap }\end{array}$ & Spatial error & $\begin{array}{c}\text { Spatial error } \\
\text { bootstrap }\end{array}$ & Robust REG & $\begin{array}{l}\text { Robust REG } \\
\text { bootstrap }\end{array}$ & PCSE \\
\hline \multirow[t]{2}{*}{ IMIG_st } & -0.0779 & -0.0736 & -0.0736 & -0.0616 & -0.0616 & -0.0305 & -0.0305 & -0.0781 \\
\hline & $(0.133)$ & $(0.0951)$ & $(0.117)$ & $(0.105)$ & $(0.116)$ & $(0.0815)$ & $(0.106)$ & $(0.0945)$ \\
\hline \multirow[t]{2}{*}{ ER_st } & 0.361 & 0.163 & 0.163 & 0.137 & 0.137 & 0.228 & $0.228^{*}$ & 0.226 \\
\hline & $(0.307)$ & $(0.117)$ & $(0.150)$ & $(0.126)$ & $(0.167)$ & $(0.122)$ & (0.114) & $(0.124)$ \\
\hline \multirow[t]{2}{*}{ EDU_tert_st } & $0.199^{*}$ & $0.250^{* * * *}$ & $0.250^{* *}$ & $0.225^{* * *}$ & $0.225^{* *}$ & $0.213^{* * *}$ & $0.213^{* *}$ & $0.320^{* * *}$ \\
\hline & $(0.0911)$ & $(0.0658)$ & $(0.0776)$ & $(0.0675)$ & $(0.0745)$ & $(0.0564)$ & $(0.0748)$ & $(0.0560)$ \\
\hline \multirow[t]{2}{*}{ EDU_part_st } & 0.0491 & -0.00899 & -0.00899 & -0.0303 & -0.0303 & 0.0407 & 0.0407 & 0.0182 \\
\hline & $(0.145)$ & $(0.0867)$ & $(0.143)$ & $(0.0915)$ & $(0.118)$ & $(0.0886)$ & (0.119) & $(0.100)$ \\
\hline \multirow[t]{2}{*}{ BERD_e_st } & -0.445 & 0.00477 & 0.00477 & -0.00416 & -0.00416 & 0.00909 & 0.00909 & -0.00988 \\
\hline & $(0.244)$ & $(0.127)$ & $(0.151)$ & $(0.135)$ & $(0.131)$ & $(0.0984)$ & $(0.0886)$ & $(0.0836)$ \\
\hline \multirow[t]{2}{*}{ ALMPs_st } & 0.119 & 0.0586 & 0.0586 & 0.0823 & 0.0823 & -0.114 & -0.114 & 0.0142 \\
\hline & $(0.167)$ & $(0.0651)$ & $(0.0958)$ & $(0.0723)$ & $(0.0927)$ & $(0.0718)$ & $(0.0872)$ & $(0.0659)$ \\
\hline \multirow[t]{2}{*}{ PLMPs_st } & $-0.568^{* * *}$ & $-0.352^{* * * *}$ & $-0.352^{* * * *}$ & $-0.327^{* * * *}$ & $-0.327^{* *}$ & $-0.300^{* * * *}$ & $-0.300^{*}$ & $-0.430^{* * *}$ \\
\hline & $(0.132)$ & $(0.0891)$ & $(0.101)$ & $(0.0984)$ & (0.119) & $(0.0801)$ & $(0.125)$ & $(0.0961)$ \\
\hline \multirow[t]{2}{*}{ GINI_st } & 0.0643 & -0.0120 & -0.0120 & 0.0344 & 0.0344 & -0.194 & -0.194 & -0.0803 \\
\hline & $(0.170)$ & $(0.126)$ & $(0.180)$ & $(0.129)$ & $(0.166)$ & (0.106) & $(0.157)$ & $(0.0999)$ \\
\hline \multirow[t]{2}{*}{ EARN_st } & $-0.966^{* * *}$ & $-0.419^{* * * *}$ & $-0.419^{* * * *}$ & $-0.384^{* * * *}$ & $-0.384^{* * * *}$ & $-0.459^{* * * *}$ & $-0.459^{* * * *}$ & $-0.557^{* * * *}$ \\
\hline & $(0.159)$ & $(0.0825)$ & $(0.111)$ & $(0.0973)$ & $(0.0967)$ & $(0.0852)$ & $(0.110)$ & $(0.134)$ \\
\hline \multirow[t]{2}{*}{ KOF_E_st } & $-0.981^{* * *}$ & -0.145 & -0.145 & -0.172 & -0.172 & -0.149 & -0.149 & -0.199 \\
\hline & $(0.196)$ & $(0.0862)$ & $(0.101)$ & $(0.0991)$ & $(0.126)$ & $(0.0793)$ & (0.129) & $(0.115)$ \\
\hline \multirow[t]{2}{*}{ _cons } & 0.0614 & -0.0409 & -0.0409 & -1.411 & $-1.411^{* * * *}$ & $0.240^{* * * *}$ & $0.240^{* * * *}$ & 0.145 \\
\hline & $(0.0733)$ & $(0.0574)$ & $(0.122)$ & (2.978) & $(0.0793)$ & $(0.0586)$ & $(0.0588)$ & $(0.179)$ \\
\hline & & $\frac{(0.0242)}{0.817^{* * * *}}$ & $\frac{(0.520)}{0.817^{* * * *}}$ & $0.836^{* * * *}$ & $0.836^{* * * *}$ & & & \\
\hline $\begin{array}{l}\text { Sigma } \\
\text { cons }\end{array}$ & & $(0.0788)$ & $(0.0910)$ & $(0.0778)$ & $(0.0736)$ & & & \\
\hline $\begin{array}{l}\text { Lambda } \\
\text { ccons }\end{array}$ & & & & $\begin{array}{l}0.974^{* * * *} \\
(0.0256)\end{array}$ & $\begin{array}{l}0.974^{*} \\
(0.424) \\
\end{array}$ & & & \\
\hline & 200 & 200 & 200 & 200 & 200 & 200 & 200 & 200 \\
\hline$R^{2}$ & 0.261 & & & & & 0.191 & 0.191 & 0.186 \\
\hline
\end{tabular}

Note: standard errors in parentheses; ${ }^{*} p<0.05,{ }^{* *} p<0.01,{ }^{* * *} p<0.001$. Source: authors' research. 
Marta-Christina Suciu, Mirela Cristea, Graţiela Georgiana Noja

\begin{tabular}{|c|c|c|c|c|c|c|c|c|}
\hline \multicolumn{9}{|c|}{ Dependent Variable: Employment rate - total (ER_st) } \\
\hline & (1) & (2) & (3) & (4) & $(5)$ & (6) & (7) & (8) \\
\hline Variables & $F E$ & $\begin{array}{l}\text { Spatial } \\
\text { lag }\end{array}$ & $\begin{array}{l}\text { Spatial lag } \\
\text { bootstrap }\end{array}$ & $\begin{array}{l}\text { Spatial } \\
\text { error }\end{array}$ & $\begin{array}{c}\text { Spatial error } \\
\text { bootstrap }\end{array}$ & $\begin{array}{c}\text { Robust } \\
\text { REG }\end{array}$ & $\begin{array}{l}\text { Robust REG } \\
\text { bootstrap }\end{array}$ & PCSE \\
\hline \multirow[t]{2}{*}{ IMIG_st } & $0.197^{* * *}$ & $0.307^{* * *}$ & $0.307^{* * * *}$ & $0.296^{* * *}$ & $0.296^{* * *}$ & $0.287^{* * *}$ & $0.287^{* * * *}$ & $0.324^{* * *}$ \\
\hline & $(0.0288)$ & $(0.0371)$ & $(0.0373)$ & $(0.0378)$ & $(0.0444)$ & $(0.0413)$ & $(0.0668)$ & $(0.0421)$ \\
\hline \multirow[t]{2}{*}{ EDU_tert_st } & 0.0222 & 0.0150 & 0.0150 & 0.00288 & 0.00288 & 0.00717 & 0.00717 & 0.00353 \\
\hline & $(0.0220)$ & $(0.0229)$ & $(0.0257)$ & $(0.0224)$ & $(0.0231)$ & $(0.0327)$ & $(0.0471)$ & $(0.0201)$ \\
\hline \multirow[t]{2}{*}{ EDU_part_st } & $0.0749^{*}$ & $0.233^{* * * *}$ & $0.233^{* * *}$ & $0.218^{* * * *}$ & $0.218^{* *}$ & $0.240^{* * *}$ & $0.240^{*}$ & $0.253^{* * * *}$ \\
\hline & $(0.0347)$ & $(0.0613)$ & $(0.0612)$ & $(0.0579)$ & $(0.0805)$ & $(0.0482)$ & (0.119) & $(0.0333)$ \\
\hline \multirow[t]{2}{*}{ BERD_e_st } & 0.0576 & $0.186^{* * *}$ & $0.186^{* *}$ & $0.207^{* * * *}$ & $0.207^{* *}$ & $0.254^{* * *}$ & $0.254^{* * *}$ & $0.187^{* * * *}$ \\
\hline & $(0.0590)$ & $(0.0555)$ & $(0.0643)$ & $(0.0573)$ & (0.0749) & $(0.0555)$ & $(0.0923)$ & $(0.0534)$ \\
\hline \multirow[t]{2}{*}{ ALMPs_st } & $-0.197^{* * * *}$ & $0.100^{*}$ & $0.100^{*}$ & 0.0966 & 0.0966 & 0.0358 & 0.0358 & $0.107^{*}$ \\
\hline & $(0.0377)$ & $(0.0475)$ & $(0.0445)$ & (0.0497) & $(0.0543)$ & $(0.0410)$ & $(0.0976)$ & $(0.0509)$ \\
\hline \multirow[t]{2}{*}{ PLMPs_st } & $-0.159^{* * *}$ & $-0.227^{* * * *}$ & $-0.227^{* * *}$ & $-0.208^{* * * *}$ & $-0.208^{* * *}$ & $-0.248^{* * * *}$ & $-0.248^{* * *}$ & $-0.213^{\text {**** }}$ \\
\hline & $(0.0298)$ & $(0.0404)$ & $(0.0420)$ & $(0.0419)$ & $(0.0425)$ & $(0.0440)$ & $(0.0648)$ & $(0.0274)$ \\
\hline \multirow[t]{2}{*}{ GINI_st } & -0.0619 & $-0.225^{* * *}$ & $-0.225^{* * *}$ & $-0.215^{* * * *}$ & $-0.215^{* *}$ & $-0.188^{* *}$ & $-0.188^{* * *}$ & $-0.237^{* * * *}$ \\
\hline & $(0.0409)$ & $(0.0548)$ & $(0.0648)$ & $(0.0558)$ & $(0.0747)$ & $(0.0591)$ & $(0.0612)$ & $(0.0574)$ \\
\hline \multirow[t]{2}{*}{ EARN_st } & $0.0793^{*}$ & $0.350^{* * * *}$ & $0.350^{* * * *}$ & $0.399^{* * * *}$ & $0.399^{* * *}$ & $0.356^{* * *}$ & $0.356^{* * *}$ & $0.376^{* * * *}$ \\
\hline & $(0.0381)$ & $(0.0420)$ & $(0.0410)$ & $(0.0443)$ & $(0.0445)$ & $(0.0416)$ & $(0.0671)$ & $(0.0420)$ \\
\hline \multirow[t]{2}{*}{ KOF_E_st } & 0.0433 & $0.219^{* * * *}$ & $0.219^{* * * *}$ & $0.256^{* * * *}$ & $0.256^{* * *}$ & $0.235^{* * * *}$ & $0.235^{* * *}$ & $0.249^{* * * *}$ \\
\hline & $(0.0473)$ & $(0.0365)$ & $(0.0312)$ & $(0.0385)$ & $(0.0316)$ & $(0.0425)$ & $(0.0562)$ & $(0.0384)$ \\
\hline \multirow[t]{2}{*}{ _cons } & -0.00162 & -0.0506 & -0.0506 & 0.0348 & 0.0348 & -0.0640 & -0.0640 & -0.0309 \\
\hline & $(0.0178)$ & $(0.0359)$ & $(0.0466)$ & $(0.202)$ & $(0.0387)$ & $(0.0340)$ & $(0.0607)$ & $(0.0241)$ \\
\hline Rho & & $0.439^{*}$ & 0.439 & & & & & \\
\hline _cons & & $(0.222)$ & $(0.310)$ & & & & & \\
\hline Sigma & & $0.450^{* * * *}$ & $0.450^{* * * *}$ & $0.442^{* * * *}$ & $0.442^{* * *}$ & & & \\
\hline _cons & & $(0.0214)$ & $(0.0233)$ & $(0.0213)$ & $(0.0202)$ & & & \\
\hline $\begin{array}{l}\text { Lambda } \\
\text { _cons }\end{array}$ & & & & $\begin{array}{l}0.806^{* * * *} \\
(0.189)\end{array}$ & $\begin{array}{l}0.806^{*} \\
(0.404)\end{array}$ & & & \\
\hline$N$ & 200 & 200 & 200 & 200 & 200 & 200 & 200 & 200 \\
\hline$R^{2}$ & 0.505 & & & & & 0.807 & 0.807 & 0.803 \\
\hline
\end{tabular}

Standard errors in parentheses; ${ }^{*} p<0.05,{ }^{* *} p<0.01,{ }^{* * *} p<0.001$. Source: authors' research. 
Immigration Effects within the EU-Brexit Framework: An Empirical Analysis

However, the impact on foreign population's employment opportunities (ER_F) and on the economic growth is uncertain (due to the lack of statistical significance of the estimated coefficients associated with BERD variable) and quite contradictory (since these coefficients are negative for the GDP_growth and ER_F impact models). Nevertheless, the passive labour market policies, PLMPs (e.g. the early retirement schemes and unemployment benefits) hinder the active labour market participation, thus leading to a major reduction of the employment rate (both on the total level of population and more severely for the foreign population).

\subsection{SEM developed to assess the impact of international labour mobility upon the economic activity in EU-10 during 2000-2019}

Aligned to our main research objective, we have evaluated the immigration effects on host countries' economic growth (measured through the real GDP growth rate) and on the labour market outcomes (measured through the employment rate)through an integrated frame of reference(SEM) to better capture the amplitude of the migration process and its multi-stage effects. Thus, from a three-fold approach, SEM captures the main implications of immigration process (both for labour/economic and the humanitarian component) in a globalization era, the labour market performances and the set of adopted policies, their inter-linkages, as well as final effects upon economic growth of the receiving countries (Figure 1).

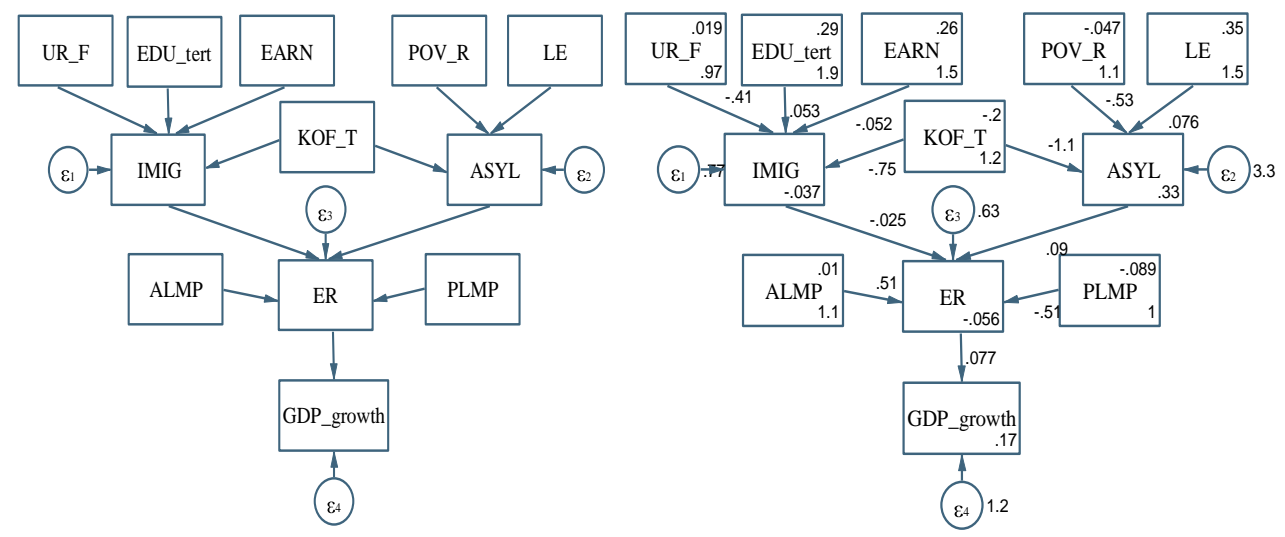

Figure 1.SEM results for the immigration impact(IMIG and ASYL) upon the economic growth and labour market in EU-10 during 2000-2019

Source: designed by the authors based on our research results

Goodness-of-fit tests (Appendix, Table A4) and Cronbach's alpha results for each element and total scale(Appendix, Table A5) highlight the reliability of the SEM model and robustness of Maximum Likelihood Estimations (MLE).Results obtained based on SEM model reveal that, when the inter-linkages between migration determinants-economic credentials-policies-final output are taken into account, the overall impact of international migration flows, both economic/labour 
(IMIG) and humanitarian (ASYL), tend to positively reverberate on host countries' economies.

Migrants tend to positively select at destination according to their educational background (especially for the high-skilled tertiary educated migrants), being attracted by higher earnings, employment opportunities and increased living standards (welfare), as shown by our results (Figure 1). Thus, additional labour immigrants and asylum seekers are drawn by improved living standards (reflected by reducing POV_R, the estimated coefficient being -0.53), and public health policies (reflected by an increase in life expectancy, LE, the estimated coefficient being 0.076).

Nevertheless, persistent high unemployment rates for the foreign population (UR_F) already residing in host economies and increased poverty risk act as a disincentive for immigrants targeting particular destinations (the estimated coefficient is -0.41). Moreover, active labour market policies (ALMP) oriented towards job creation and educational programmes have important positive effects leading to an increase in employment levels (the coefficient is 0.51 ), while passive policies (PLMP, especially the unemployment benefits) tend to deteriorate labour market participation rate (the estimated coefficient is -0.51). All these positive and negative dimensions reverberate on final economic growth of host economies (the estimated coefficient is 0.077 ), and therefore are considered to be extremely important by policy makers across Europe, especially in the context of Brexit.

\section{CONCLUDING REMARKS}

This research aimed to examine the immigration effects upon economic growth and labour market outcomes(both for own and for the foreign people)for EU-10 MS in the context of Brexit framework. Labour mobility is one of the four fundamental manifestation of freedom for the European integration process and a major thematic invoked by the UK in motivating its decision to exit from the EU. According to this broader framework, we have designed two scenarios of the expected outcomes accomplished by the EU-10 MS(including the UK)expressed in terms of GDP growth rates and correspondingly of employment anticipated levels under the impact of the trends of the international migratory flows considered within the Brexit context, respectively during 2000-2019 (2019 being the deadline for Brexit negotiations).

Our main research results reveal a strong positive immigration impact upon host countries' labour markets reflected through important increases in employment rates (both overall and mainly for the foreign population), on the one side. On the other side, the impacts on GDP growth rates could not be properly captured, since the estimated coefficients have a reduced degree of statistical significance throughout the eight econometric methods processed. Though, when we have applied the integrated framework for the analysis of labour immigration impacts in this regard (SEM models), we could notice that, if the inter-linkages between migration determinants - economic credentials - policies - final output are taken 
Immigration Effects within the EU-Brexit Framework: An Empirical Analysis

into account, the overall impacts of immigration flows, both labour (economic) and humanitarian, tend to have positive expected effects reflected on the host countries' economies.

Our main research results obtained are in line with previous similar studies (Chu, 2016) and show that a possible slowdown of economic growth after the Brexit shock could be mitigated through continuous support of labour mobility and not by reinforcing barriers in this respect.

Our results support positive credentials of migration, consistent with Booth et al. (2015), which reveal that policies supporting the free movement of people will significantly contribute to the raise of the total GDP by 2030.Labour mobility after Brexitin Europe will certainly influence both migrant sending and hosting economies, since it will be reconfigured under new migration policies and regulations adopted by EU-27 and by the UK.

In order to enhance the results of our study, we aim to include in our future research a bilateral matrix approach by extending the panel so as to comprise migrant sending economies as well.

\section{REFERENCES}

[1]Begg, I,Mushövel, F.(2016), The Economic Impact of Brexit: Jobs, Growth and the Public Finances.The London School of Economics and Political Science, European Institute, London, UK;

[2]Boboc, C., Boncea, I., Manea, D. (2015), The International Migration of Romanian Physicians. Economic Computation \& Economic Cybernetics Studies \& Research; ASE Publishing; 49(4), 85-102;

[3]Booth, S., Howarth, C., Persson, M., Ruparel, R., Swidlicki, P. (2015), What If? The Consequences, Challenges and Opportunities Facing Britain outside the $\boldsymbol{E} \boldsymbol{U}$.Open Europe, London, UK;

[4]Boswell, C. (2016), Migration: Would Limiting the Free Movement of Labour Be Good or Bad?. In: Jeffery, C., Perman, R. "Britain's Decision: Facts and Impartial Analysis for the EU referendum on 23 June 2016". Edinburgh: The David Hume Institute;

[5]Boubtane, E., Dumont, J.C., Rault, C. (2015), Immigration and Economic Growth in the OECD Countries 1986-2006. CESIFO Working Paper, 5392, 1-36. doi:10.1093/oep/gpw001;

[6]Chu, B. (2016), Post-Brexit Britain Would Need to Keep Migration High to Prevent Economic Fallout. The Independent, March 22;

[7]Clarke, S., Whittaker, M. (2016), The Importance of Place: Explaining the Characteristics Underpinning the Brexit Vote across Different Parts of the UK". Available at: http://www.resolutionfoundation.org/wpcontent/uploads/2016/07/Brexit-vote-v4.pdf;

[8]Comes, C.A., Bunduchi, E., Vasile, V., Stefan, D. (2018), The Impact of Foreign Direct Investments and Remittances on Economic Growth: A Case Study in Central and Eastern Europe. Sustainability, 10(1), 238; 
Marta-Christina Suciu, Mirela Cristea, Graţiela Georgiana Noja

[9]Efron, B., Tibshirani, R.J. (1994), An Introduction to the Bootstrap.Chapman \& Hall, CRC Monographs on Statistics \& Applied Probability;

[10]European Commission(2017), Eurostat Database.Available at:

http://ec.europa.eu/eurostat;

[11]ETH Zurich(2018), KOF Swiss Economic Institute. Available at:

https://www.kof.ethz.ch/en/;

[12]Irwin, G. (2015), BREXIT: The Impact on the UK and the EU.Global

Counsel;

[13]Jafari, Y., Britz, W. (2017), Brexit - An Economy-wide Impact Assessment

Looking into Trade, Immigration, and Foreign Direct Investment. In: 20th

Annual Conference on Global Economic Analysis "Global Economic Analysis in the 21st Century: Challenges and Opportunities", West Lafayette, Indiana, USA;

[14]Kierzenkowski, R., Pain, N., Rusticelli, E., Zwart, S. (2016), The Economic Consequences of Brexit: A Taxing Decision.The OECD Economic Policy Paper Series, 16;

[15]Marcu, N., Dobrotă, C.E. (2016), The Economic Impact of the Cohesion Policy. Revista Economica, 68(3), 74-93;

[16]Netoiu, T., Cârstina, S., Selisteanu, A. (2014), Correlation Analysis between Indicators that Define the Labour Market in the European Union. Procedia Economics and Finance, 8, 138-143;

[17]Noja, G.G., Cristea, S.M., Yüksel, A., Pânzaru, C., Drăcea, R.M. (2018), Migrants' Role in Enhancing the Economic Development of Host Countries: Empirical Evidence from Europe.Sustainability, 10(3), 894. doi:10.3390/su10030894;

[18] OECD (2005), Handbook on Constructing Composite Indicators:

Methodology and User Guide. OECD Publishing, Paris, France;

[19]OECD (2017), International Migration Outlook. Trends in Migration Flows. Available athttp://dx.doi.org/10.1787/migr_outlook-2017-en;

[20]Parker, O. (2017), Critical Political Economy, Free Movement and Brexit: beyond the Progressive's Dilemma. British Journal of Politics and International Relations, 19(3). 479-496. Available at:

https://doi.org/10.1177/1369148117711082;

[21]Portes, J. (2016), Immigration after Brexit. National Institute Economic Review, 238;

[22]Portes, J.,Forte, G. (2017), The Economic Impact of Brexit-Induced

Reductions in Migration. Oxford Review of Economic Policy, 33(suppl 1), S31-

S44. Available at: https://doi.org/10.1093/oxrep/grx008;

[23]Roman, M., Popescu, M.E.(2015), The Effects of Training on Romanian

Migrants'income: A Propensity Score Matching Approach. Economic

Computation \& Economic Cybernetics Studies \& Research, 49(1), 105-12;

[24]Sampson, T.(2017), Brexit: The Economics of International

Disintegration. Journal of Economic Perspectives, 31(4), 163-184; 
Immigration Effects within the EU-Brexit Framework: An Empirical Analysis

[25]Simionescu (Bratu), M., Strielkowshi, W., Kalyugina, S. (2017), The Impact of Brexit on Labour Migration and Labour Markets in the United

Kingdom and the EU.Terra Economicus, 15(1). doi 10.18522/2073-6606-2017-151-148-156;

[26]United Nations, Department of Economic and Social Affairs (UN DESA)(2015), Trends in International Migrant Stock: Migrants by Destination and Origin. United Nations database, POP/DB/MIG/Stock/Rev.2015;

[27]Un Refugee Agency (UNHCR) (2017), Figures at a Glance 2017. Available at:http://www.unhcr.org/figures-at-a-glance.html;

[28]Viton P.A. (2010), Notes on Spatial Econometric Models. City and Regional Planning, 870, 9-10;

[29]World Bank (2017), World Development Indicators.Available at:

https://data.worldbank.org/indicator, last accessed 2017/08/17. 
Marta-Christina Suciu, Mirela Cristea, Graţiela Georgiana Noja

\section{Appendix}

Table A1. Descriptive statistics of the variables, 2000-2019 sample

\begin{tabular}{lcrrrr}
\hline Variables & $N$ & \multicolumn{1}{c}{ Mean } & \multicolumn{1}{c}{$s d$} & \multicolumn{1}{c}{$\min$} & \multicolumn{1}{c}{$\max$} \\
\hline IMIG & 200 & 305259.6 & 308797.9 & 16895 & 1845793 \\
ASYL & 200 & 48116.55 & 67278.9 & 1405 & 490520 \\
ER & 200 & 67.1235 & 6.344435 & 53.7 & 77.9 \\
ER_F & 200 & 61.071 & 5.591304 & 45.2 & 74.4 \\
UR & 200 & 7.401 & 2.238156 & 2.100001 & 15.7 \\
UR_F & 200 & 13.6625 & 5.508645 & 3.600001 & 35.4 \\
EARN & 200 & 54223.53 & 13303.79 & 28412 & 113749 \\
ALMPs & 200 & 0.663075 & 0.3801446 & 0.035 & 1.973 \\
PLMPs & 200 & 1.342235 & 0.6662019 & -.0039999 & 3.053 \\
EDU_tert & 200 & 26.62 & 8.937471 & 8.1 & 75.89999 \\
EDU_part & 200 & 18.4625 & 11.81902 & -6.7 & 95.3 \\
POV_R & 200 & 20.49 & 4.646142 & 9.1 & 30.30001 \\
LE & 200 & 80.8375 & 2.011485 & 76.2 & 87.39998 \\
BERD & 200 & 1.28585 & .5970249 & 0.38 & 2.985 \\
GINI & 200 & 28.85 & 3.588049 & 20.6 & 39.7 \\
KOF_T & 200 & 84.6848 & 4.524084 & 74.94002 & 92.63 \\
KOF_E & 200 & 76.4758 & 10.08743 & 49.08002 & 94.8 \\
\hline
\end{tabular}

Source: own process in Stata

Table A2. Unit Root Tests of the Residuals, Models for Immigration-GDP_growth Impact, 2000-2019

Residuals

\begin{tabular}{llc}
\hline & p-value & 0.0159 \\
LLC (Levin-Lin-Chu) & t-statistic & -2.1473 \\
& ADF regressions: 1 lag & \\
& LR variance: Bartlett kernel, 8.00 lags average \\
\hline & p-value & 0.0001 \\
& t-statistic & -2.9054 \\
& Test critical values: & -2.210 \\
& & -1.990 \\
Im-Pesaran-Shin & & -1.890 \\
& ADF regressions: No lags included & \\
& AR (Autoregressive) parameter: Panel-specific \\
\hline & p-value & 0.0000 \\
Harris-Tzavalis & Statistic & 0.4315 \\
& Z & -9.0995 \\
\hline Fisher-type & p-value & 0.0000 \\
Based on Augmented Dickey- & Inverse chi-squared (56) & 78.5494 \\
Fuller (ADF) tests & Modified inv. chi-squared & 9.2575 \\
\hline Ho: (All/ Some) Panels contain unit roots & \\
Ha: Panels are stationary/ At least one panel is stationary & \\
\hline Source: authors' research in Stata & &
\end{tabular}


Immigration Effects within the EU-Brexit Framework: An Empirical Analysis

\begin{tabular}{|c|c|c|c|c|c|c|c|c|}
\hline \multicolumn{9}{|c|}{ Var. Dep: Employment rate of the foreign population (ER_F_st) } \\
\hline & (1) & & (5) & (6) & (7) & (8) & (9) & (10) \\
\hline Variables & $F E$ & Spatial lag & $\begin{array}{c}\text { Spatial lag } \\
\text { bootstrap }\end{array}$ & $\begin{array}{l}\text { Spatial } \\
\text { error }\end{array}$ & $\begin{array}{c}\text { Spatial error } \\
\text { bootstrap }\end{array}$ & $\begin{array}{c}\text { Robust } \\
\text { REG }\end{array}$ & $\begin{array}{c}\text { Robust REG } \\
\text { bootstrap }\end{array}$ & PCSE \\
\hline IMIG_st & $\begin{array}{l}0.347^{* * *} \\
(0.0541)\end{array}$ & $\begin{array}{l}0.278^{* * * *} \\
(0.0786)\end{array}$ & $\begin{array}{l}0.278^{* * * * *} \\
(0.0631)\end{array}$ & $\begin{array}{l}0.281^{* * * *} \\
(0.0706)\end{array}$ & $\begin{array}{l}0.281^{* * * *} \\
(0.0637)\end{array}$ & $\begin{array}{l}0.322^{* * * *} \\
(0.0675)\end{array}$ & $\begin{array}{l}0.322^{* * * *} \\
(0.0747)\end{array}$ & $\begin{array}{l}0.308^{* * *} \\
(0.0528)\end{array}$ \\
\hline EDU_tert_st & $\begin{array}{c}0.0325 \\
(0.0413)\end{array}$ & $\begin{array}{c}-0.0213 \\
(0.0555)\end{array}$ & $\begin{array}{c}-0.0213 \\
(0.0568)\end{array}$ & $\begin{array}{c}-0.00965 \\
(0.0575)\end{array}$ & $\begin{array}{c}-0.00965 \\
(0.0584)\end{array}$ & $\begin{array}{c}-0.0172 \\
(0.0534)\end{array}$ & $\begin{array}{c}-0.0172 \\
(0.0790)\end{array}$ & $\begin{array}{c}-0.0204 \\
(0.0514)\end{array}$ \\
\hline EDU_part_st & $\begin{array}{c}-0.0505 \\
(0.0652)\end{array}$ & $\begin{array}{c}0.160 \\
(0.134)\end{array}$ & $\begin{array}{c}0.160 \\
(0.143)\end{array}$ & $\begin{array}{c}0.149 \\
(0.139)\end{array}$ & $\begin{array}{c}0.149 \\
(0.151)\end{array}$ & $\begin{array}{l}0.332^{* * *} \\
(0.0787)\end{array}$ & $\begin{array}{l}0.332^{*} \\
(0.168)\end{array}$ & $\begin{array}{l}0.171^{* *} \\
(0.0616)\end{array}$ \\
\hline BERD_e_st & $\begin{array}{c}0.196 \\
(0.111)\end{array}$ & $\begin{array}{c}-0.127 \\
(0.0906)\end{array}$ & $\begin{array}{c}-0.127 \\
(0.0996)\end{array}$ & $\begin{array}{c}-0.142 \\
(0.0902)\end{array}$ & $\begin{array}{l}-0.142 \\
(0.104)\end{array}$ & $\begin{array}{c}-0.107 \\
(0.0907)\end{array}$ & $\begin{array}{c}-0.107 \\
(0.0995)\end{array}$ & $\begin{array}{c}-0.132 \\
(0.0733)\end{array}$ \\
\hline ALMPs_st & $\begin{array}{l}-0.302^{* * * *} \\
(0.0707)\end{array}$ & $\begin{array}{c}0.0401 \\
(0.0587)\end{array}$ & $\begin{array}{c}0.0401 \\
(0.0601)\end{array}$ & $\begin{array}{l}0.0342 \\
(0.0610)\end{array}$ & $\begin{array}{c}0.0342 \\
(0.0623)\end{array}$ & $\begin{array}{c}0.0402 \\
(0.0669)\end{array}$ & $\begin{array}{c}0.0402 \\
(0.0631)\end{array}$ & $\begin{array}{c}0.0403 \\
(0.0619)\end{array}$ \\
\hline PLMPs_st & $\begin{array}{c}-0.594^{* * *} \\
(0.0559)\end{array}$ & $\begin{array}{l}-0.555^{* * * *} \\
(0.0563)\end{array}$ & $\begin{array}{l}-0.555^{\text {**** }} \\
(0.0588)\end{array}$ & $\begin{array}{c}-0.581^{* * * * *} \\
(0.0652)\end{array}$ & $\begin{array}{l}-0.581^{* * * *} \\
(0.0566)\end{array}$ & $\begin{array}{c}-0.526^{* * * *} \\
(0.0718)\end{array}$ & $\begin{array}{l}-0.526^{* * * *} \\
(0.0706)\end{array}$ & $\begin{array}{c}-0.554^{* * * *} \\
(0.0634)\end{array}$ \\
\hline GINI_st & $\begin{array}{c}-0.371^{* * *} \\
(0.0768)\end{array}$ & $\begin{array}{c}-0.0726 \\
(0.0906)\end{array}$ & $\begin{array}{c}-0.0726 \\
(0.0971)\end{array}$ & $\begin{array}{c}-0.0730 \\
(0.0899)\end{array}$ & $\begin{array}{l}-0.0730 \\
(0.0952)\end{array}$ & $\begin{array}{c}-0.0106 \\
(0.0966)\end{array}$ & $\begin{array}{c}-0.0106 \\
(0.1000)\end{array}$ & $\begin{array}{c}-0.0787 \\
(0.109)\end{array}$ \\
\hline EARN_st & $\begin{array}{c}0.197^{* *} \\
(0.0715)\end{array}$ & $\begin{array}{c}0.0914 \\
(0.0708)\end{array}$ & $\begin{array}{c}0.0914 \\
(0.0653)\end{array}$ & $\begin{array}{c}0.0784 \\
(0.0720)\end{array}$ & $\begin{array}{c}0.0784 \\
(0.0739)\end{array}$ & $\begin{array}{c}0.0398 \\
(0.0680)\end{array}$ & $\begin{array}{l}0.0398 \\
(0.119)\end{array}$ & $\begin{array}{c}0.0926 \\
(0.0582)\end{array}$ \\
\hline KOF_E_st & $\begin{array}{c}0.182^{*} \\
(0.0888)\end{array}$ & $\begin{array}{c}0.144 \\
(0.0781)\end{array}$ & $\begin{array}{c}0.144^{*} \\
(0.0638)\end{array}$ & $\begin{array}{c}0.133 \\
(0.0784)\end{array}$ & $\begin{array}{c}0.133 \\
(0.0913)\end{array}$ & $\begin{array}{c}0.172^{*} \\
(0.0694)\end{array}$ & $\begin{array}{c}0.172 \\
(0.116)\end{array}$ & $\begin{array}{c}0.148^{* *} \\
(0.0504)\end{array}$ \\
\hline _cons & $\begin{array}{r}-0.0284 \\
(0.0334) \\
\end{array}$ & $\begin{array}{l}0.00215 \\
(0.0681) \\
\end{array}$ & $\begin{array}{l}0.00215 \\
(0.0658) \\
\end{array}$ & $\begin{array}{l}0.0182 \\
(0.135) \\
\end{array}$ & $\begin{array}{c}0.0182 \\
(0.0695) \\
\end{array}$ & $\begin{array}{r}0.0262 \\
(0.0554) \\
\end{array}$ & $\begin{array}{c}0.0262 \\
(0.0866) \\
\end{array}$ & $\begin{array}{r}-0.0150 \\
(0.0508) \\
\end{array}$ \\
\hline $\begin{array}{l}\text { Rho } \\
\text { cons }\end{array}$ & & $\begin{array}{c}0.248 \\
(0.396) \\
\end{array}$ & $\begin{array}{c}0.248 \\
(0.401) \\
\end{array}$ & & & & & \\
\hline $\begin{array}{c}\text { Sigma } \\
\text { cons }\end{array}$ & & $\begin{array}{l}0.714^{* * * *} \\
(0.0375)\end{array}$ & $\begin{array}{l}0.714^{* * * *} \\
(0.0385)\end{array}$ & $\begin{array}{l}0.711^{* * * *} \\
(0.0373)\end{array}$ & $\begin{array}{l}0.711^{* * *} \\
(0.0328)\end{array}$ & & & \\
\hline $\begin{array}{l}\text { Lambda } \\
\text { _cons }\end{array}$ & & & & $\begin{array}{c}0.486 \\
(0.528) \\
\end{array}$ & $\begin{array}{c}0.486 \\
(0.442) \\
\end{array}$ & & & \\
\hline $\begin{array}{l}N \\
R^{2}\end{array}$ & $\begin{array}{c}200 \\
0.612\end{array}$ & 200 & 200 & 200 & 200 & $\begin{array}{c}200 \\
0.520\end{array}$ & $\begin{array}{c}200 \\
0.520\end{array}$ & $\begin{array}{c}200 \\
0.515\end{array}$ \\
\hline
\end{tabular}

Standard errors in parentheses; ${ }^{*} p<0.05,{ }^{* *} p<0.01,{ }^{* * *} p<0.001$. Source: authors' research in Stata. 
Marta-Christina Suciu, Mirela Cristea, Graţiela Georgiana Noja

Table A4. Goodness-of-fit tests for SEM, 2000-2019

\begin{tabular}{|c|c|c|}
\hline Fit statistic & Value & Description \\
\hline \multicolumn{3}{|l|}{ Likelihood ratio (LR) } \\
\hline chi2_ms(26) & \multicolumn{2}{|c|}{ 366.200model vs. saturated } \\
\hline $\mathrm{p}>\operatorname{chi} 2$ & \multicolumn{2}{|c|}{0.000} \\
\hline chi2_bs(38) & \multicolumn{2}{|c|}{ 683.845baseline vs. saturated } \\
\hline $\mathrm{p}>$ chi 2 & \multicolumn{2}{|c|}{0.000} \\
\hline \multicolumn{3}{|l|}{ Information criteria } \\
\hline AIC & \multicolumn{2}{|c|}{ 6785.422Akaike's information criterion } \\
\hline $\mathrm{BIC}$ & \multicolumn{2}{|c|}{ 6851.389Bayesian information criterion } \\
\hline \multicolumn{3}{|l|}{ Baseline comparison } \\
\hline CFI & \multicolumn{2}{|c|}{ 0.473Comparative fit index } \\
\hline TLI & \multicolumn{2}{|c|}{ 0.230Tucker-Lewis index } \\
\hline \multicolumn{3}{|l|}{ Size of residuals } \\
\hline SRMR & 0.097 & Standardized root mean squared residual \\
\hline $\mathrm{CD}$ & 0.764 & Coefficient of determination \\
\hline
\end{tabular}

Source: authors' research in Stata.

Table A5. Results for Cronbach's alpha, SEM, 2000-2019

\begin{tabular}{lcccccc}
\hline \multicolumn{7}{l}{ Test scale = mean (standardized items) } \\
\hline Average & \multicolumn{7}{l}{$l$} & \\
\hline Item & Obs & Sign & $\begin{array}{l}\text { Item-test } \\
\text { correlation }\end{array}$ & $\begin{array}{l}\text { Item-rest } \\
\text { correlation }\end{array}$ & $\begin{array}{l}\text { Inter-item } \\
\text { correlation }\end{array}$ & alpha \\
\hline GDP_growth & 200 & + & 0.3137 & 0.1389 & 0.1564 & 0.6710 \\
IMIG & 200 & + & 0.5662 & 0.4238 & 0.1310 & 0.6238 \\
ASYL & 200 & + & 0.6381 & 0.5108 & 0.1238 & 0.6084 \\
EARN & 200 & + & 0.7014 & 0.5900 & 0.1174 & 0.5940 \\
EDU_tert & 200 & + & 0.3287 & 0.1550 & 0.1549 & 0.6685 \\
UR_F & 200 & - & 0.4641 & 0.3049 & 0.1413 & 0.6441 \\
KOF_T & 200 & - & 0.4829 & 0.3264 & 0.1394 & 0.6405 \\
POV_R & 200 & - & 0.2199 & 0.0403 & 0.1659 & 0.6863 \\
LE & 200 & + & 0.3451 & 0.1727 & 0.1533 & 0.6657 \\
ER & 200 & + & 0.5125 & 0.3606 & 0.1364 & 0.6347 \\
ALMPs & 200 & - & 0.2628 & 0.0849 & 0.1616 & 0.6794 \\
PLMPs & 200 & - & 0.7040 & 0.5933 & 0.1171 & 0.5934 \\
\hline Total scale & \multicolumn{7}{c}{0.1415} & 0.6643 \\
\hline Source: authors' research in Stata.
\end{tabular}

